\title{
Mortality predictors in acute exacerbation of COPD: A prospective study in Western India
}

\author{
Dharmeshkumar S Patel ${ }^{1}$, Rushi R. Patel2,,
}

Assistant Professor, Dept. of Respiratory Medicine, GCS Medical College, Hospital \& Research Centre, Ahmedabad, Gujarat, India

*Corresponding Author:

Email: rrpate19@gmail.com

\begin{abstract}
Introduction: Chronic Obstructive Pulmonary Disease (COPD) is a leading cause of morbidity and mortality world-wide. In 2016, COPD was the third leading cause of death. Thus prevention, early detection and prompt treatment of exacerbations may have an impact on the clinical progression and the risk of hospitalization.

Material and Methods: This is a prospective study of 94 patients admitted for acute exacerbation of COPD in a tertiary care hospital over a period of 18 months. After a detailed medical history and physical examination, patients' blood was sent for Arterial Blood Gas (ABG) analysis, a complete hemogram, blood sugar levels, serum albumin levels, blood urea nitrogen levels (BUN), serum creatinine levels, SGPT, SGOT, serum sodium and potassium levels. We have then compared these parameters in the patients who have died with those who have survived to determine mortality predictors.

Result: A statistically significant corelation was observed between male gender, smoking (odd ratio of 1.5), duration of smoking $(\mathrm{p}=0.0014)$, history of prior admission (odd ratio of 2), longer duration of illness $(\mathrm{p}=0.045)$, elevated blood sugar levels $(\mathrm{p}=0.035)$, hypolabuminemia $(0.001)$, hyponatremia $(0.001)$, respiratory acidosis $(0.003)$, elevated partial pressure of $\mathrm{CO}_{2}(0.001)$ and mortality.

Conclusion: We found a male preponderance of increased mortality. Increase in mortality was also there with the increase in the duration of smoking. Longer duration of illness was also an important predictor of mortality. Respiratory acidosis, hyponatremia, elevated blood sugar levels and hypoalbuminemia at the time of presentation are other important predictors of mortality in patients hospitalized for acute exacerbation of COPD.
\end{abstract}

Keywords: Acute exacerbation; Chronic obstructive pulmonary disease (COPD); Predictors; Mortality.

\section{Introduction:}

Chronic Obstructive Pulmonary Disease (COPD) is a leading cause of mortality and morbidity worldwide [1]. The prevalence of COPD is directly related to the prevalence of tobacco smoking, although in many countries outdoor, occupational and indoor air pollution resulting from burning of wood and other biogas fuels are major COPD risk factors [2].

The prevalence and mortality due to COPD are projected to increase over the coming decades due to continued exposure to COPD risk factors. In 2016, COPD was the third leading cause of death in the United States. Globally there are around three million deaths annually due to COPD [3]. It is estimated that by 2030 there may be over 4.5 million deaths annually from COPD [4]. COPD exacerbations affect the quality of life and prognosis of patients. Older age, decreased lung functions, lower health status, Diabetes Mellitus and prior hospital admission are important risk factors for mortality. COPD is associated with significant economic burden. COPD exacerbations account for the greatest proportion of the total COPD burden on the health care system. Hospitalization and ambulatory oxygen costs soar with increasing COPD severity.

It is important to identify at the time of admission, patients who are likely to have a poor outcome, so that such patients can be managed aggressively. Many prognostic factors have been devised for the same.
These help to segregate patients who are likely to have better outcome. The present study was conducted to determine the predictors of mortality in acute exacerbation of COPD admitted to a tertiary care hospital.

\section{Material and Methods:}

This is a prospective study of 94 patients admitted for Acute Exacerbation of COPD in a tertiary care hospital over a period of 18 months. A COPD exacerbation was defined by the presence of an increase in at least two of the following three symptoms of dyspnoea, cough and sputum purulence severe enough to warrant hospitalization [5]. All patients were documented cases of COPD as per GOLD (Global Initiative for Chronic Obstructive Lung Disease) guidelines with prior spirometry confirmation of irreversible obstructive airway disease [5]. A detailed history and demography of all patients was taken including history of smoking, exposure to occupational dust, biomass fuel gas and exposure to other noxious gases.

History of hospitalization in the previous year, ICU stay, history of concomitant illnesses and previous history of pulmonary tuberculosis were noted. All patients were then subjected to a detailed clinical examination. Temperature, pulse, blood pressure, oxygen saturation by pulse oximetry were noted. At the 
time of admission, blood was sent for a complete hemogram, blood sugar levels, serum proteins, serum SGPT, serum SGOT, serum creatinine, serum sodium and potassium levels. Patients were also subjected to a chest radiograph, electrocardiogram and a 2Dimensional Echocardiography. We did not include patients with haemodynamic instability requiring ICU admission, patients with other life threatening conditions and patients who refused to give consent.

The patients were managed as per GOLD guidelines for the management of severe but not life threatening exacerbations [5]. Patients were administered nasal oxygen through a venturi mask wherever needed. They were given nebulized Salbutamol and Ipratropium, oral Prednisolone in the dose of $40 \mathrm{mg}$ once daily, and intra venous antibiotics when signs of bacterial infection were present. The fluid balance was monitored and managed in all patients, and any concomitant illness was managed according to the respective guidelines. The patients were followed up either till discharge or death.

\section{Results:}

A total of 94 patients were enrolled over 18 months. The patients were aged between 45-76 years, with a mean age of 60.5 years, with majority patients between 51-70 years. The male: female ratio was 3.7:1. Out of 94 patients, $64(68.1 \%)$ patients were either smokers or ex-smokers (those who left smoking before 1 year) and $30(31.9 \%)$ were non-smokers (those who have never smoked). Out of 94 patients, 78 (83\%) were discharged while $16(17 \%)$ died of which $14(87.5 \%)$ were males and $2(12.5 \%)$ were females (table 1$)$.

Table 1: Sex distribution and mortality relation amongst patients admitted for acute exacerbation of COPD

\begin{tabular}{|l|c|c|c|}
\hline \multicolumn{1}{|c|}{ Status } & Male & Female & Total \\
\hline Discharged & $60(77 \%)$ & $18(23 \%)$ & $78(100 \%)$ \\
\hline Expired & $14(87.5 \%)$ & $2(12.5 \%)$ & $16(100 \%)$ \\
\hline Total & 74 & 20 & 94 \\
\hline
\end{tabular}

Table 2: Relation between smoking and mortality in patients admitted for acute exacerbation of COPD

\begin{tabular}{|l|c|c|c|c|}
\hline & Survived & Expired & Total & Odd Ratio \\
\hline Smoker & $52(67 \%)$ & $12(75 \%)$ & 64 & \multirow{2}{*}{1.5} \\
\cline { 1 - 4 } Non-smoker & $26(33 \%)$ & $4(25 \%)$ & 30 & \\
\cline { 1 - 3 } Total & $78(100 \%)$ & $16(100 \%)$ & 94 & \\
\hline
\end{tabular}

Among the patients who survived, $67 \%$ were smokers and among the patients who expired during hospital stay, $75 \%$ were smokers. So mortality was more common among smokers with an odd ratio of 1.5.

Table 3: Relation between smoking duration in years and mortality in patients admitted for acute exacerbation of COPD

\begin{tabular}{|l|l|c|c|c|c|c|}
\hline & Status & Number & $\begin{array}{c}\text { Mean } \\
\text { (duration in } \\
\text { years) }\end{array}$ & $\begin{array}{c}\text { Standard } \\
\text { Deviation } \\
\text { ( STD+/-) }\end{array}$ & $\begin{array}{c}\text { Standard } \\
\text { Error } \\
\text { Mean }\end{array}$ & P value \\
\hline \multirow{2}{*}{ Pack Year } & Survived & 52 & 17.7 & 8.54 & 1.18 & 0.0014 \\
\cline { 2 - 6 } & Expired & 12 & 26.67 & 7.47 & 2.15 & \\
\hline
\end{tabular}

Among the patients who survived (78), 52 were smokers with a mean duration of smoking for 17.7 years; and among those who died (16), 12 were smokers with a mean duration of smoking for 26.67 years. This difference is statistically significant ( $\mathrm{p}$ value is 0.0014 ), thus demonstrating a strong relation between the duration of smoking and mortality.

Of the 16 patients who died, $12(75 \%)$ had history of prior admissions for COPD exacerbation in the previous one year (Table 4). Patients with longer duration of illness had greater mortality ( $\mathrm{p}$ value $=0.045)($ table 5)

Table 4: Relation between prior hospital admission for COPD exacerbation in previous year and mortality in patients admitted for acute exacerbation of COPD

\begin{tabular}{|l|c|c|c|}
\hline \multirow{2}{*}{ Status } & Prior hospitalization for COPD exacerbation & \multirow{2}{*}{ Total } \\
\cline { 2 - 3 } & Present & Absent & \\
\hline Survived & $46(59 \%)$ & $32(41 \%)$ & $78(100 \%)$ \\
\hline Expired & $12(75 \%)$ & $4(25 \%)$ & $16(100 \%)$ \\
\hline Total & 58 & 36 & \\
\hline
\end{tabular}


Table 5: Relation between total duration of illness and mortality in patients admitted for acute exacerbation of COPD

\begin{tabular}{|c|l|c|c|c|c|c|}
\hline Variable & Status & Number & $\begin{array}{c}\text { Mean } \\
\text { (years) }\end{array}$ & $\begin{array}{c}\text { Standard } \\
\text { Deviation } \\
\text { (SD+/-) }\end{array}$ & $\begin{array}{c}\text { Standard } \\
\text { Error Mean }\end{array}$ & P value \\
\hline $\begin{array}{l}\text { Total duration } \\
\text { of Illness }\end{array}$ & Survived & 78 & 13.51 & 5.519 & 0.625 & 0.045 \\
\cline { 2 - 7 } & Expired & 16 & 16.62 & 5.909 & 1.477 & \\
\hline
\end{tabular}

Table 6: Relation between laboratory parameters and mortality in patients admitted for acute exacerbation of COPD

\begin{tabular}{|c|c|c|c|c|c|c|}
\hline Variable & Status & $\begin{array}{c}\text { Number of } \\
\text { patients }\end{array}$ & Mean & $\begin{array}{l}\text { Standard } \\
\text { deviation }\end{array}$ & $\begin{array}{l}\text { Standard } \\
\text { error mean }\end{array}$ & $P$ value \\
\hline \multirow[t]{2}{*}{ Haemoglobin } & Survived & 58 & $13.297 \mathrm{gm} \%$ & 2.7129 & 0.3562 & \multirow[t]{2}{*}{0.716} \\
\hline & Expired & 16 & $13.640 \mathrm{gm} \%$ & 2.9497 & 0.9328 & \\
\hline \multirow{2}{*}{$\begin{array}{l}\text { Total } \\
\text { leucocyte } \\
\text { count }\end{array}$} & Survived & 78 & 13140 & 3997.478 & 452.625 & \multirow[t]{2}{*}{0.138} \\
\hline & Expired & 16 & 15340 & 9822.695 & 2455.674 & \\
\hline \multirow{2}{*}{$\begin{array}{l}\text { Random } \\
\text { Blood Sugar }\end{array}$} & Survived & 76 & $167.13 \mathrm{mg} \%$ & 94.214 & 10.807 & \multirow[t]{2}{*}{0.035} \\
\hline & Expired & 16 & $231.62 \mathrm{mg} \%$ & 165.893 & 41.473 & \\
\hline \multirow{2}{*}{$\begin{array}{l}\text { Serum } \\
\text { Albumin }\end{array}$} & Survived & 74 & $3.39 \mathrm{gm} \%$ & 0.33699 & 0.03917 & \multirow[t]{2}{*}{0.001} \\
\hline & Expired & 16 & $3.05 \mathrm{gm} \%$ & 0.37872 & 0.09468 & \\
\hline \multirow[t]{2}{*}{ Blood Urea } & Survived & 78 & $63.04 \mathrm{mg} \%$ & 36.693 & 4.155 & \multirow[t]{2}{*}{0.542} \\
\hline & Expired & 14 & $69.29 \mathrm{mg} \%$ & 24.228 & 6.475 & \\
\hline \multirow{2}{*}{$\begin{array}{l}\text { Serum } \\
\text { Creatinine }\end{array}$} & Survived & 78 & $1.4590 \mathrm{mg} \%$ & 0.62987 & 0.07132 & \multirow[t]{2}{*}{0.870} \\
\hline & Expired & 14 & $1.4700 \mathrm{mg} \%$ & 0.47390 & 0.12666 & \\
\hline \multirow{2}{*}{$\begin{array}{l}\text { Serum } \\
\text { sodium }\end{array}$} & Survived & 74 & $135.92 \mathrm{mEq} / \mathrm{dl}$ & 6.221 & 0.723 & \multirow[t]{2}{*}{0.001} \\
\hline & Expired & 14 & $123.43 \mathrm{mEq} / \mathrm{dl}$ & 10.825 & 2.893 & \\
\hline \multirow{2}{*}{$\begin{array}{l}\text { Serum } \\
\text { Potassium }\end{array}$} & Survived & 74 & $4.451 \mathrm{mEq} / \mathrm{dl}$ & 1.1233 & 0.1306 & \multirow[t]{2}{*}{0.410} \\
\hline & Expired & 14 & $4.186 \mathrm{mEq} / \mathrm{dl}$ & 0.9566 & 0.2557 & \\
\hline \multirow{2}{*}{$\begin{array}{l}\mathrm{PaO} 2 \\
\mathrm{ABG}\end{array}$} & Survived & 76 & $56.80 \mathrm{mmHg}$ & 17.206 & 1.974 & \multirow[t]{2}{*}{0.845} \\
\hline & Expired & 16 & $55.88 \mathrm{mmHg}$ & 16.705 & 4.176 & \\
\hline \multirow{2}{*}{$\begin{array}{l}\mathrm{PaCO} 2 \text { in } \\
\mathrm{ABG}\end{array}$} & Survived & 76 & $53.182 \mathrm{mmHg}$ & 15.4171 & 1.7685 & \multirow[t]{2}{*}{0.001} \\
\hline & Expired & 16 & $72.088 \mathrm{mmHg}$ & 33.4712 & 8.3678 & \\
\hline \multirow[t]{2}{*}{$\mathrm{pH}$ in $\mathrm{ABG}$} & Survived & 76 & 7.39889 & 0.070122 & 0.008044 & \multirow[t]{2}{*}{0.003} \\
\hline & Expired & 16 & 7.30350 & 0.107542 & 0.026886 & \\
\hline \multirow[t]{2}{*}{ Serum HCO3 } & Survived & 76 & $32.245 \mathrm{mEq} / \mathrm{dl}$ & 8.9514 & 1.0268 & \multirow[t]{2}{*}{0.385} \\
\hline & Expired & 16 & $34.712 \mathrm{mEq} / \mathrm{dl}$ & 12.8490 & 3.2123 & \\
\hline
\end{tabular}

Patients with increased blood sugar levels (mean random blood sugar levels of $213.62 \mathrm{mg} \%$ ), lower serum albumin levels (mean serum albumin levels of $3.05 \mathrm{gm} \%$ and lower serum sodium levels (mean serum sodium levels of $123.43 \mathrm{mEq} / \mathrm{dl}$ ) had an increased mortality which was statistically significant. Statistically higher mortality was observed when the Arterial Blood Gas (ABG) at the time of admission showed an acidic $\mathrm{pH}$ (mean $\mathrm{pH}$ of 7.3035) and a higher $\mathrm{PaCO}_{2}$ levels (mean $\mathrm{PaCO}_{2}$ of $72.088 \mathrm{mmHg}$ ) (Table 6).

\section{Discussion:}

The main objective of the study was to evaluate the predictors of mortality in acute exacerbation of COPD. Patient characteristics related to an increased mortality rate were analysed. Out of 94 patients admitted, 16 (17\%) died during hospital stay. This observation was supported by study done by Connors et al who reported an in- hospital mortality of $11 \%$ and Fuso et al who reported an in- hospital mortality rate of $14.4 \%$ [6,7].

In this study, of the 16 patients who died, 2 were females (12.5\%) and 14 were males $(87.5 \%)$ (Table 1$)$. This may be due to the fact that smoking habits are more common in males in India [8].

We observed that the mortality was 1.5 times higher among smokers than non smokers (odd ratio 1.5). (Table 2). Smokers who died had a mean duration of smoking for 26.67 years against those who survived (mean duration of smoking was 17.7 years). Thus this concludes that long duration of smoking is an independent predictor of mortality in patients with acute exacerbation of COPD (Table 3).

In our study out of the 16 patients who died, 12 (75\%) patients gave history of hospitalization for acute exacerbation of COPD in the previous year (Table 4). 
Several studies have shown that prior admission to hospital increases mortality in COPD exacerbation $[6,9]$.

There is a high incidence of mortality in patients with a longer duration of illness (Table 5). The mean total duration of COPD in the survived group was 13.51 years and in the patients who died it was 16.62 years. The long duration of illness implies a more severe disease due to gradual decline in lung functions with passing years. Thus duration of illness is also an important predictor of mortality in patients admitted with COPD exacerbation.

On comparing the ABG of the two groups of patients in our study, it was seen that patients who died had a lower partial pressure of oxygen compared to those patients who survived, though this difference was not statistically significant. This finding is supported by Karin $\mathrm{H}$ Groenewegen et al, but was contrary to observations made by Almagro et al. $[9,10]$ The patients who died had a higher level of partial pressure of carbon dioxide $(72.088 \mathrm{mmHg})$ as compared to the survivors $(53.182 \mathrm{mmHg})$. This difference was statistically significant $[6,7,9,10]$.

In our study mean $\mathrm{pH}$ of patients who died was 7.30350 as compared to the survivors (7.39889) which was statistically significant. The acidosis was predominantly respiratory, due to elevated $\mathrm{PaCO}_{2}$. Acidosis at the time of acute presentation is thus an important predictor of mortality.

An elevated $\mathrm{HCO}_{3}$ levels were seen in both the groups of patients. The difference was not statistically significant [11]. The increase in $\mathrm{HCO} 3$ levels compensate the respiratory acidosis. Acute respiratory acidosis which is not compensated is a risk factor for mortality in patients of acute exacerbation of COPD.

It was observed in our study that the difference in the Blood Urea Nitrogen and serum creatinine levels in the two groups were not significantly and thus did not predict mortality, a similar findings found in several studies $[11,12]$. This was however contrary to a study which showed serum creatinine to be an independent predictor of mortality [13].

Also in our study, patients with hyponatremia had a higher mortality as compared with patients with normal serum sodium levels $(\mathrm{p}=0.001)$ as documented in literature [13].

We did not observe a significant difference in the haemoglobin levels and the total leucocyte count in both the groups. In both the groups, the total leucocyte count was elevated which indicates infection as the cause of exacerbation of COPD in our patients.

Our study shows hyperglycemia at the time of admission as one of the predictors of mortality in acute exacerbation of COPD. The mean random blood sugar of patients who died was $231.62 \mathrm{mg} / \mathrm{dl}$ compared to $167.13 \mathrm{mg} / \mathrm{dl}$ in the survivors. Previous studies have not commented on random blood sugar levels at the time of admission as mortality factor. Diabetes is an important co-morbidity in patients with COPD. Previous studies have shown that COPD patients with hyperglycemia are more prone for getting secondary infection. Patients with hyperglycemia and COPD also have a higher incidence of coronary artery disease which is again an important cause of mortality in COPD patients $[14,15]$.

In our study a low serum albumin levels at the time of admission was an important predictor of mortality, with the difference in the two groups being statistically significant. This observation is supported by a study which concluded that serum albumin levels in the first 24 hours of admission is an independent predictor of mortality in patients with acute exacerbation of COPD $[16,17]$.

\section{Conclusion:}

In this prospective study of hospitalized patients with acute exacerbation of COPD, we summarize the predictors of mortality. We found a male preponderance of increased morality. Increase in mortality was also there with the increase in the duration of smoking. Longer duration of illness was also an important predictor of mortality. Respiratory acidosis (with decrease in $\mathrm{pH}$ and an increase in $\mathrm{PaCO}_{2}$ ), hyponatremia, elevated blood sugar levels and hypoalbuminemia at the time of presentation are other important predictors of mortality in patients hospitalized for acute exacerbation of COPD.

\section{References:}

1. American Lung Association Epidemiology and Statistics Unit. Trends in COPD (Chronic Bronchitis and Emphysema): Morbidity and Mortality [Internet]. Chicago, IL: American Lung Association Epidemiology and Statistics Unit; March 2013 [cited 2018 Feb 10]. Available from: http://www.lung.org/assets/documents/research/copdtrend-report.pdf

2. Eisner MD, Anthonisen N, Coultas T, et al. An Official American Thoracic Society public policy statement: Novel risk factors and the global burden of chronic obstructive pulmonary disease. Am J Respir Crit Care Med 2010;182(5):693-718.

3. Global, regional, and national age-sex specific all cause and cause- specific mortality for 240 causes of death, 1990-2013: a systematic analysis for the Global Burden of Disease Study 2013. Lancet 2015;385(9963):117-71.

4. Lopez AD, Shibuya K, Rao C, et al. Chronic obstructive pulmonary disease: current burden and future projections. Eur Respir J 2006;27(2):392-412.

5. From the Global Strategy for the Diagnosis, Management and Prevention of COPD, Global Initiative for Chronic Obstructive Lung Disease (GOLD) 2017. Available from: https://goldcopd.org.

6. Connors AF, Jr, Dawson NV, Thomas C, et al. Outcomes following acute exacerbation of severe chronic obstructive lung disease: the SUPPORT Investigators [errantum published in Am J Respir Crit Care Med 1997;155:386] Am J Respir Crit Care Med 1996;154:959-67.

7. Fuso L, Incalzi RA, Pistelli R, et al. Predicting mortality of patients hospitalized for acutely exacerbated chronic 
obstructive pulmonary disease. Am J Med 1995;98(3):272-77.

8. Ministry of Health and Family Welfare, Government of India. Global Adult Tobacco Survey, GATS India 20092010 [Internet]. New Delhi, India: Ministry of Health and Family Welfare, Government of India; 2010 [cited 2018 Feb 10]. Available from:

www.who.int/tobacco/surveillance/india_fact_sheet.pdf

9. Almagro P, MD, Calbo E, MD, de Echaguen AO, et al. Mortality after Hospitalisation for COPD. Chest 2002;121(5):1441-48.

10. Groenewegen KH, MD, Annemie MW, et al. Mortality and Morbidity- Related Factors After Hospitalisation for Acute Exacerbation of COPD. Chest 2003;124(2):459-67.

11. Gray DK, Gibbons L, Shapiro SH, et al. Nutritional status and mortality in chronic obstructive pulmonary disease. Am J Respir Crit Care Med 1996;153(3):961-66.

12. Seneff MG, Wagner DP, Wagner RP, et al. Hospital and 1 - year survival of patients admitted to intensive care units with exacerbation of chronic obstructive pulmonary disease. JAMA 1995;274:1852-57.

13. Sukumalchandra Y, Dinakara P, Williams MH, et al. Prognosis of patients with chronic obstructive pulmonary disease after hospitalisation for acute ventilatory failure: a three- year follow-up study. Am Rev Respir Dis 1996;93:215-22.

14. Mannino DM, Thorn D, Swensen A, et al. Prevalence and outcomes of diabetes, hypertension and cardiovascular disease in COPD. Eur Respir J 2008;32(4):962-69.

15. Yeh HC, Punjabi NM, Wang NY, et al. Cross-sectional and prospective study of lung functions in adults with type 2 diabetes: the Artherosclerosis Risk in Communities (ARIC) study. Diabetes Care 2008;31(4):741-46.

16. Khilnani GC, Amit Banga, Sharma SK. Predictors of mortality of patients with acute respiratory failure secondary to chronic obstructive pulmonary disease admitted to an intensive care unit: a 1- year study. BMC Pulmonary Medicine. 2004;4:12.

17. Bhatt SP, et al. Predictors of in-hospital mortality and morbidity in patients with acute exacerbation of chronic obstructive pulmonary disease. Chest. 2006;130(4):97-8.

How to cite this article: Patel DK. S., Patel R. R. Mortality predictors in acute exacerbation of COPD: A prospective study in Western India. IP Indian $J$ Immunol Respiratory Med 2018;3(3):103-107. 